\title{
ANALISIS DIPLOMASI INDONESIA - MALAYSIA DALAM MASALAH PERBATASAN
}

\author{
Achdijat Sulaeman \\ Dosen Program Studi Hubungan Internasional FISIP \\ Universitas Al-Ghifari Bandung \\ sachdijat@yahoo.co.id
}

\begin{abstract}
ABSTRAK
Fungsi utama Diplomasi adalah melindungi dan memajukan kepentigan nasional dalam artikel ini akan membahas analisis diplomasi Indonesia dan Malaysia dalam sengketa perbatasan, Hal ini akan dikaji dengan melihat dari sisi hubungan internasional yang kemudian dikaji pula keuntungan dan kerugiannya dilihat dari sisi kebijakan dan upayaupaya yang dilakukan oleh pemerintah untuk kepentingan dalam negeri maupun luar negeri. Oleh sebab itu, pada bagian ini diketengahkan berbagai kajian hubungan internasional, kebijakan, serta aktivitas masyarakat. Indonesia dan Malaysia merupakan bangsa satu rumpun Melayu dan mayoritas penduduknya sama - sama beragama Muslim. Selalu diantara kedua Negara ini tersandung batu seperti beberapa kasus TKI, lepasnya kedua pulau terluar Sipadan - Ligitan, kasus di perbatasan Ambalat, pencekalan lagu Indonesia di Malaysia, pengklaiman kebudayaan Reog, Batik, lagu Rasa Sayange dan sederet masalah akan menjadi benang merah apabila ditarik mundur kedalam kacamata sejarah dimasa lalu.
\end{abstract}

Kata kunci : Diplomasi, Konflik, Negosiasi, Mediasi, Konsiliasi

\begin{abstract}
The main function of diplomacy is to protect and promote national identity in this article will discuss the analysis of Indonesia and Malaysia diplomacy in border disputes, This will be examined by looking at the international relations which is then reviewed also the advantages and disadvantages seen in terms of policies and efforts made by the government for domestic and foreign purposes. Therefore, in this section the various studies of International Relations policy as well as activities of Indonesian society and Malaysia are the nation of one Malay family and the majority of the population are Muslim. Always between these two countries stumble stones like some cases of migrant workers, the loss of the two islands Sipadan Ligitan, the case on the Ambalat border, the Indonesian Indonesian tracking in Malaysia, the claiming of the Reog culture, the Batik, the Rasa Sayange song and a series of problems will become a common thread when dith retreats into the eyeglasses of the past.
\end{abstract}

Key words : Diplomacy, Conflict, Negotiation, Mediation, Conciliation

\section{A. Latar Belakang}

Beberapa kasus yang terjadi dengan negara tetangga seperti Malaysia ini memang bagaikan api dalam sekam, meskipun antara Indonesia dan Malaysia 
merupakan bangsa satu rumpun Melayu dan mayoritas penduduknya sama - sama beragama Muslim. Entah kenapa diantara kedua Negara ini tersandung batu seperti beberapa kasus TKI, lepasnya kedua pulau terluar Sipadan - Ligitan, kasus di perbatasan Ambalat, pencekalan lagu Indonesia di Malaysia, pengklaiman kebudayaan Reog, Batik, lagu Rasa Sayange dan sederet masalah akan menjadi benang merah apabila ditarik mundur kedalam kacamata sejarah dimasa lalu.

Beberapa kasus yang terjadi dengan negara tetangga seperti Malaysia ini memang bagaikan api dalam sekam, meskipun antara Indonesia dan Malaysia merupakan bangsa satu rumpun Melayu dan mayoritas penduduknya sama - sama beragama Muslim. Entah kenapa diantara kedua Negara ini tersandung batu seperti beberapa kasus TKI, lepasnya kedua pulau terluar Sipadan - Ligitan, kasus di perbatasan Ambalat, pencekalan lagu Indonesia di Malaysia, pengklaiman kebudayaan Reog, Batik, lagu Rasa Sayange dan sederet masalah akan menjadi benang merah apabila ditarik mundur kedalam kacamata sejarah dimasa lalu.

Penulis melihat bahwa hal tersebut disebabkan oleh kurangnya rasa nasionalisme yang dilakukan terhadap mayarakat, kurangnya upaya melibatkan masyarakat dan pemerintah, dan lemahnya sosialisasi kebudayaan sebagai manfaat dari jati diri bangsa.

Untuk menganalisis permasalahan diatas berdasarkan identintifikasi masalah dan perumusan masalah yang akan diteliti maka masalah yang akan dianalisis dalam artikel ini yaitu ;Bagaimana upaya penyelesaian persengketaan perbatasan antara Indonesia dan Malaysia?. Bagaimana dampak dari persengketaan perbatasan Indonesia dan Malaysia?

Untuk menganalisis kasus ini penulis ingin mengetahui cara untuk menyelesaikan permasalahan persengketaan perbatasan ini diantaranya dengan cara Diplomasi. Kata diplomasi di yakini berasal dari kata yunani "diploum" yang berarti "melipat" karena pada zaman romawi, semaua paspor dicetak apda piringan logan yang kemudian dilipat dan dijahit. Selanjutnya kata ini berkembang dan mencakup pula dokumen-dokumen resmi yang bukan logam. Khususnya yang memberikan hak istimewa tertentu ataun menyangkut perjanjian dengan suku bangsa asing di luar bangsa romawi. (S.L. Roy, Diplomasi, Rajawali press,Jakarta,1991:1).

Fungsi utama Diplomasi adalah melindungi dan memajukan kepentigan nasional. Beberapa pengertian Diplomasi munurut para ahli seperti:

1. Menurut sumaryo suryokusumo, Diplomasi adalah kegiatan politik dan merupakan bagian dari kegiatan internasional yang saling berpengaruh dan kompleks, dengan melibatkan pemerintahan dan organisasi internasional untuk mencapai tujuan - tujuannya, melalui perwakilan diplomatik atau orang - organ lainnya.

2. Menurut Sir Victor Wellesley, diplomasi bukan suatu kebijakan, melainkan upaya untuk memberikan pengaruh terhadap kebijakan atau pandangan negara lain.

3. Menurut Nicholas, diplomasi yang berkualitas dan keberhasilan politik luar negeri tidak tergantung pada tujuan yang abstrak melainkan pada pelaksanaan diplomasi yang nyata melalui berbagai cara, yaitu dengan menyebarkan kebijakan yang diambil, menjelaskan dan merundingkan 
persetujuan - persetujuan yang menjamin keamanan negara baik perang maupun damai.

Persengketaan Indonesia dan Malaysia telah terjadi sejak dulu, Pengertian sengketa dalam kamus Bahasa Indonesia, berarti pertentangan atau konflik, Konflik berarti adanya oposisi atau pertentangan antara orang-orang, kelompok-kelompok, atau organisasi-organisasi terhadap satu objek permasalahan. Dapat dikatakan bahwa sengketa adalah prilaku pertentangan antara dua orang atau lebih yang dapat menimbulkan suatu akibat hukum dan karenanya dapat diberi sangsi hukum bagi salah satu diantara keduanya. Sedangkan menurut Ali Achmad berpendapat: "Sengketa adalah pertentangan antara dua pihak atau lebih yang berawal dari persepsi yang berbeda tentang suatu kepentingan atau hak milik yang dapat menimbulkan akibat hukum bagi keduanya."

Dari pendapat para ahli diatas maka dapat dikatakan bahwa sengketa adalah prilaku pertentangan antara dua orang atau lebih yang dapat menimbulkan suatu akibat hukum dan karenanya dapat diberi sangsi hukum bagi salah satu diantara keduanya .

Semenjak demonstrasi anti Indonesia di kuala Lumpur, ketika para demonstran menyerbu gedung KBRI, merobek foto Soekarno, membawa lambang garauda pancasila ke hadapan Tunku Abdul Rahman yaitu perdana menteri Malaysia pada saat itu dan memaksana untuk menginjak Garuda. Hal itu tentu saja membuat presiden negara indonesia saat itu yaitu Soekarno sangat marah,Bukan karena kalimantan utara tidak masuk Indonesia saja melainkan akibat tindakan Tunku yang menginjak - nginjak lambang negara Indonesia, maka dari itu Soekarno melakukan balasan dengan melancarkan gerakan yg terkenal dengan sebutan Ganyang Malaysia kepada negara federasi Malaysia yang telah sangat menghina Indonesia dan Presiden Indonesia.

Kekhawatiran presiden indonesia saat itu sangat beralasan.karena melihat pengalaman masa lalu, saat negara jepang di boncengi Belanda yang ingin menjajah indonesia kembali. Maka semanjak kejadian itu negara indonesia mengambil pengalaman agar tidak di kuasai lagi oleh negara lain,dan indonesia bisa menjadi negara yang merdeka dan berdaulat seutuhnya.

Akibat dari ketidak setujuan penggabungan itu, rakyat di sekitar kalimantan utara mulai merasakan dampaknya yaitu peperangan. peperangan terjadi bukan antara tentara indonesia melawan malaysia, melainkan antara pasukan Tentara Nasional Kalimantan Utara (TKNU) melawan tentara Inggris. Melihat itu peperangan itu dapat dilihat bahwa kaliantan utara benar-benar akan di jadikan negara boneka inggris, karena malaysia tidak ikut campur mengenai masalah ini.malah yang berperan adalah negara inggris.

Peperangan di wilayah kalimantan timur terus berlangsung tanpa melibatkan pemerintah indonesia secara langsung meskipun permasalahan ini sudah diatasi secara diplomasi. Hal itu karena malaysia mengkhianati isi perjanjian yaitu sabah dan serawak yang dalam perjanjian semula wilayah tersebut bukan merupakan milik malaysia,namun sabah dan serawak akhirnya jatuh di tangaan malaysia. Setelah kejadian itu presiden Soekarno memutuskan negara indonesia keluar dari PBB pada tanggal 7 januari 1965 karena Soekarno sudah kecewa dengan keputusan tersebut. 
Setelah kejadian tersebut, bahkan sampai sekarang pertikaian antara indonesia dengan malaysia masih berlanjut. Contohnya pengklaiman tarian Reog Ponorogo, Batik, dan masih banyak lagi kebudayaan-kebudayaan indonesia lainnya yang di klaim oleh malaysia. Itu semua terjadi karena ke sembronoan dan kekurang ajaran malaysia dan ketidak tegasan dan ketidak berdayaan negara indonesia.

Dalam artikel analisis diplomasi Indonesia dan Malaysia dalam sengketa perbatasan ini akan dikaji dengan melihat dari sisi hubungan internasional yang kemudian dikaji pula keuntungan dan kerugiannya dilihat dari sisi kebijakan dan upaya-upaya yang dilakukan oleh pemerintah untuk kepentingan dalam negeri maupun luar negeri. Oleh sebab itu, pada bagian ini diketengahkan berbagai kajian hubungan internasional, kebijakan, serta aktivitas masyarakat.

Diplomasi terdiri dari teknik - teknik dan prosedur - prosedur pelaksanaan hubungan antar negara. Jadi sebenarnya merupakan alat yang normal dari pelaksanaan hubungan internasional. Diplomasi sendiri seperti halnya dengan alat, mesin atau instrumen lainnya adalah netral, terlepas dari nilai - nilai apakah bermoral atau tidak bermoral (immoral).

Diplomasi bekerja melalui departemen - departemen atau kementerian kementerian luar negeri, kedutaan - kedutaan besar, legasi -legasi, konsulat konsulat dan misi - misi khusus diseluruh dunia. Pada umumnya sifat bilateral, tetapi sebagai akibat dari makin pentingnya arti konperensi - konperensi internasional, organisasi - organisasi internasional dan regional dan tindakantindakan untuk keamanan bersamamaka aspek - aspeknya yang bersifat multylateral makin penting. Diplomasi dapat meliputi berbagai macam kepentingan mulai dari soal - soal sederhana sampai masalah - masalah vital seperti perang dan perdamaian. Kalau diplomasi gagal, putus maka bahaya perang atau paling sedikit suatu krisis yang gawat akan timbul.

Politik Luar Negeri erat kaitannya dengan diplomasi akan tetapi kita perlu membatasi pengertian antara diplomasi dan politik Luar negeri (foreign policy) dan diplomasi dalam buku Pengantar Ilmu Hubungan Internasional (1967:164) J.R Childs dalam bukunya American foreign Service, Holt, 1948 mengatakan :

the foreigm policy of a state is the substance of foreign relations, whereas diplomacy proper is the process by which policy is carried out. (politik luar negeri dari suatu negara adalah merupakan isi poko dari hubungan luar negerinya, sedangkan diplomasi adalah proses pelaksanaan politik itu).

Politik (kebijaksanaan) dibuat atatu ditetapkankan pleh berbagai tokoh dan oleh lembaga - lembaga atau badan - badan, tetapi agaknya pada setiap negara, bagaimanapun bentuk pemerintahannya, soal - soal penting atau kebijaksanaan kebijaksanaan penting dibuat pada tingkat - tingkat tertinggi meskipun dapat di kontrol atau di awasi dengan berbagai cara.

Obyek (tujuan) dari diplomasi, seperti juga dari politik luar negeri, adalah untuk melindungi dan menjamin keamanan suatu negara kalau mungkin dengan cara - cara damai, tetapi juga memberikan bantuannya kepada operasi - operasi militer jika perang tak dapat dihindarkan lagi. 
Diplomasi tidak berhenti bekerja dalam waktu perang, meskipun peranannya lain(belainan). Mungkin tugas dari pada diplomasi dan para menteri luar negeri makin luas/bertambah. Ini dapat dibuktikan oleh diplomasi selama dua perang duni dalam abad 20 ini.

Perbatasan adalah garis khayalan yang memisahkan dua atau lebih wilayah politik atau yurisdiksi seperti Negara, Negara bagian atau wilayah subnasional Indonesia merupakan negara kepulauan dengan garis pantai sekitar 81.900 kilometer, memiliki wilayah perbatasan dengan banyak negara baik perbatasan darat (kontinen) maupun laut (maritim). Batas darat wilayah Republik Indonesia berbatasan langsung dengan negara-negara Malaysia, Papua New Guinea (PNG) dan Timor Leste. Perbatasan darat Indonesia tersebar di tiga pulau, empat Provinsi dan 15 kabupaten/kota yang masing-masing memiliki karakteristik perbatasan yang berbeda-beda. Demikian pula negara tetangga yang berbatasannya baik bila ditinjau dari segi kondisi sosial, ekonomi, politik maupun budayanya. Sedangkan wilayah laut Indonesia berbatasan dengan 10 negara, yaitu India, Malaysia, Singapura, Thailand, Vietnam, Filipina, Republik Palau, Australia, Timor Leste dan Papua Nugini (PNG). Wilayah perbatasan laut pada umumnya berupa pulau-pulau terluar yang jumlahnya 92 pulau dan termasuk pulau-pulau kecil. Beberapa diantaranya masih perlu penataan dan pengelolaan yang lebih intensif karena mempunyai kecenderungan permasalahan dengan negara tetangga.

Peraturan Presiden Nomor 7 Tahun 2005 tentang Rencana Pembangunan Jangka Menengah Nasional (RPJM-Nasional 2004-2009) telah menetapkan arah dan pengembangan wilayah Perbatasan Negara sebagai salah satu program prioritas pembangunan nasional. Pembangunan wilayah perbatasan memiliki keterkaitan yang sangat erat dengan misi pembangunan nasional, terutama untuk menjamin keutuhan dan kedaulatan wilayah, pertahanan keamanan nasional, serta meningkatkan kesejahteraan rakyat di wilayah perbatasan. Paradigma baru, pengembangan wilayah-wilayah perbatasan adalah dengan mengubah arah kebijakan pembangunan yang selama ini cenderung berorientasi inward looking, menjadi outward looking sehingga wilayah tersebut dapat dimanfaatkan sebagai pintu gerbang aktivitas ekonomi dan perdagangan dengan negara tetangga. Pendekatan pembangunan wilayah Perbatasan Negara menggunakan pendekatan kesejahteraan (prosperity approach) dengan tidak meninggalkan pendekatan keamanan (security approach). Sedangkan program pengembangan wilayah perbatasan (RPJM Nasional 2004-2009), bertujuan untuk : (a) menjaga keutuhan wilayah NKRI melalui penetapan hak kedaulatan NKRI yang dijamin oleh Hukum Internasional; (b) meningkatkan kesejahteraan masyarakat setempat dengan menggali potensi ekonomi, sosial dan budaya serta keuntungan lokasi geografis yang sangat strategis untuk berhubungan dengan negara tetangga. Disamping itu permasalahan perbatasan juga dihadapkan pada permasalahan keamanan seperti separatisme dan maraknya kegiatan-kegiatan ilegal.

Peraturan Presiden Nomor 39 Tahun 2005 tentang Rencana Kerja Pemerintah Tahun 2006 (RKP 2006) telah pula menempatkan pembangunan wilayah perbatasan sebagai prioritas pertama dalam mengurangi disparitas pembangunan antarwilayah, dengan program-program antara lain : Percepatan pembangunan prasarana dan sarana di wilayah perbatasan, pulau-pulau kecil terisolir 
melalui kegiatan : (i) untuk wilayah perbatasan, terkait dengan pendidikan, kesehatan, kelautan dan perikanan, irigasi, dan transportasi, (ii) penerapan skim kewajiban layanan publik dan keperintisan untuk transportasi dan kewajiban layanan untuk telekomunikasi serta listrik pedesaan; Pengembangan ekonomi di wilayah Perbatasan Negara; Peningkatan keamanan dan kelancaran lalu lintas orang dan barang di wilayah perbatasan, melalui kegiatan : (i) penetapan garis batas negara dan garis batas administratif, (ii) peningkatan penyediaan fasilitas kapabeanan, keimigrasian, karantina, komunikasi, informasi, dan pertahanan di wilayah Perbatasan Negara (CIQS); Peningkatan kapasitas kelembagaan pemerintah daerah yang secara adminstratif terletak di wilayah Perbatasan Negara.

Komitmen pemerintah melalui kedua produk hukum ini pada kenyataannya belum dapat dilaksanakan sebagaimana mestinya karena beberapa faktor yang saling terkait, mulai dari segi politik, hukum, kelembagaan, sumberdaya, koordinasi, dan faktor lainnya.

Sebagian besar wilayah perbatasan di Indonesia masih merupakan daerah tertinggal dengan sarana dan prasarana sosial dan ekonomi yang masih sangat terbatas. Pandangan dimasa lalu bahwa daerah perbatasan merupakan wilayah yang perlu diawasi secara ketat karena menjadi tempat persembunyian para pemberontak telah menjadikan paradigma pembangunan perbatasan lebih mengutamakan pada pendekatan keamanan dari pada kesejahteraan. Sebagai wilayah perbatasan di beberapa daerah menjadi tidak tersentuh oleh dinamika sehingga pembangunan dan masyarakatnya pada umumnya miskin dan banyak yang berorientasi kepada negara tetangga. Di lain pihak, salah satu negara tetangga yaitu Malaysia, telah membangun pusat-pusat pertumbuhan dan koridor perbatasannya melalui berbagai kegiatan ekonomi dan perdagangan yang telah memberikan keuntungan bagi pemerintah maupun masyarakatnya. Demikian juga Timor Leste, tidak tertutup kemungkinan dimasa mendatang dalam waktu yang relatif singkat, melalui pemanfaatan dukungan internasional, akan menjadi negara yang berkembang pesat, sehingga jika tidak diantisipasi provinsi NTT yang ada di perbatasan dengan negara tersebut akan tetap tertinggal.

Dengan berlakunya perdagangan bebas baik ASEAN maupun internasional serta kesepakatan serta kerjasama ekonomi baik regional maupun bilateral, maka peluang ekonomi di beberapa wilayah perbatasan darat maupun laut menjadi lebih terbuka dan perlu menjadi pertimbangan dalam upaya pengembangan wilayah tersebut. Kerjasama sub-regional seperti AFTA (Asean Free Trade Area), IMS-GT (Indonesia Malaysia Singapura Growth Triangle), IMT-GT (Indonesia Malaysia Thailand Growth Triangle), BIMP-EAGA (Brunei, Indonesia, Malaysia, PhilipinaEast Asian Growth Area) dan AIDA (Australia Indonesia Development Area) perlu dimanfaatkan secara optimal sehingga memberikan keuntungan kedua belah pihak secara seimbang. Untuk melaksanakan berbagai kerjasama ekonomi internasional dan sub-regional tersebut Indonesia perlu menyiapkan berbagai kebijakan dan langkah serta program pembangunan yang menyeluruh dan terpadu sehingga Indonesia tidak akan tertinggal dari negara-negara tetangga yang menyebabkan sumberdaya alam yang tersedia terutama di wilayah perbatasan akan tersedot keluar tanpa memberikan keuntungan bagai masyarakat dan pemerintah. Sarana dan prasarana ekonomi dan sosial yang dibutuhkan dalam rangka pelaksanaan kerjasama 
bilateral dan sub-regional perlu disiapkan. Penyediaan sarana dan prasarana ini tentunya membutuhkan biaya yang sangat besar, oleh karena itu diperlukan penentuan prioritas baik lokasi maupun waktu pelaksanaannya.

Rencana Induk Pengelolaan Perbatasan ini diharapkan dapat memberikan prinsip-prinsip pengembangan wilayah Perbatasan Negara sesuai dengan karakteristik fungsionalnya untuk mengejar ketertinggalan dari daerah di sekitarnya yang lebih berkembang ataupun untuk mensinergikan dengan perkembangan negara tetangga. Selain itu, kebijakan dan strategi ini nantinya juga ditujukan untuk menjaga atau mengamankan wilayah Perbatasan Negara dari upaya-upaya eksploitasi sumberdaya alam yang berlebihan, baik yang dilakukan oleh masyarakat maupun yang dilakukan dengan dorongan kepentingan negara tetangga, sehingga kegiatan ekonomi dapat dilakukan secara lebih selektif dan optimal. Ada empat wilayah Indonesia yang berbatasan langsung dengan Malaysia, diantaranya yaitu, Sungai Buan; Titik D 400; Gunung Raya dan Sungai Aum.

\section{B. Analisis}

Kedua Negara, Indonesia dan Malaysia sama - sama memberikan hak konsesi eksplorasi dikawasan yang sama kepada perusahaan yang berbeda. Melda Kamil Ariadno, dalam salah satu artikelnya menyebut hal ini sebagai dua klaim yang saling tumpang tindih antara dua Negara bertetangga (overlapping claim areas).

Salah satu contoh persengketaan perebutan Blok Ambalat ini menimbulkan efek nasiaonalisme yang luar biasa dari warga Negara Indonesia di berbagai belahan nusantara. Unjuk rasa atau pernytaan sikap terjadi dimana - mana, baik dilakukan oleh kelompok mahsiswa, jajaran legislatif ataupun masyarakat pada umumnya, intinya mereka menuntut pemerintah Indonesia agara bersikap tegas dalam mempertahankan kedaulatan wilayah Negara Indonesia ini, jangan sampai jatuh ketangan Malaysia.

Situasi di daerah perbatasan ikut memanas, kedua Negara mengerahkan peraltan militernya baik udara, darat maupun laut sebagai bentuk kesiapan mereka dalam menjaga kedaulatan wilayahnya. Dari berbagai persengketan yang mewarnai hubungan Indonsesia/Malaysia diatas, khususnya peresngketaan baru dalam perebutan Blok Ambalat hendaknya agar tetap diselesaikan secara damai. Penyelesaian sengketa secara damai adalah cara yang dianjurkan oleh dunia internasional.

Adalah merupakan ketentuan hukum positif bahwa penggunaan kekerasan dalam hubungan antar Negara telah dilarang dan oleh karena itu sengketa - sengketa internasional harus diselesaikan secara damai. Keharusan menyelesaikan sengketa secara damai pada mulanya dicantumkan dalam pasal 1 konvensi mengenai pernyelesaian sengketa - sengketa secara damai yang ditanda tangani di Den Haag pada 18 Oktober 1907, kemudian di kukuhkan oleh pasal 2 ayat (3) paiagam PBB dan selanjutnya oleh Deklarasi prinsip - prinsip hukum internasional mengenai hubungan bersahabat dan kerjasama antar Negara yang diterima oleh majelis umum PBB pada 24 Oktober 1970. Deklarasi ini meminta kepada semua Negara untuk menyelesaikan sengketa mereka dengan cara damai sedemikian rupa agar perdamaian, keamanan internasional, dan keadilan tidak sampai terganggu. 
Hukum Internasional tidak berisi keharusan agara suatu Negara memilih prosedur penyelesaian tertentu. Hal ini ditegaskan dalam pasal 33 (1) piagam PBB yang meminta kepada Negara - negara untuk menyelesaikan secara damai sengketa - sengketa mereka sesuai dengan kesepakatan yang telah dibuat. Sebagai bukti bahwa penyelesaian sengeketa secara damai bias menyelesaikan sengketa, dapat dilihat melalui berbagai perundingan yang dilakukan oleh perewakilan Indonesia, baik setingkat kepala Negara, setingkat menteri ataupun delegasi yang bertsifat khusus, berbagai persengketaan seperti permasalahan TKI dapat terselesaikan dengan baik tanpa adanya konfrontasi militer. Bukti lain, walaupun gagal melalui meja perundingan dan memerlukan waktu yang lama akhirnya diteruskan melalui Mahkamah Internasional, Indonesia dan Malaysia bias menyelesaikan sengketa atas kepemilikan Pulau Sipadan dan Pulau Ligitan secara damai tanpa adanya konfrontasi militer. Jika melihat contoh kasus perebutan Blok Ambalat, maka kasus tersebut bisa dikategorikan sengketa mengenai implementasi hukum laut internasional. Unsur - unsur yang mempengaruhi kasus tersebut sedikit banyak mengenai hukum laut internasional, dimana masalah penetapan batas wiliyah territorial laut antara Indonesia/Malaysia menjadi inti dari kasus perebutan Blok Ambalat, walaupun dilain pihak unsur ekonomi masuk kedalamnya.

Penerapan metode penyelesaian sengketa secara damai sesuai dengan yang dianjurkan dalam United Nations Conventions On The Law Of the Sea 1982 (UNCLOS 1982) bisa diterapkan, mengingat Indonesia dan Malaysia sudah meratifikasi konvensi tersebut.

Konvesi Hukum laut 1982 menyediakan berbagai metode dalam rangka penyelesaian sengketa hokum laut. Dilihat dari perkembangan system peradilan internasional, mekanisme konvensi ini merupakan yang pertama kali dapat mengarahkan Negara - Negara peserta untuk menerima prosedur memaksa (compulsory procedures), dengan system konvesi maka tidak ada lagi ruang bagi Negara - negara pihak konvensi untuk menunda - nunda sengeketa hukum lautnya dengan bersembunyi di belakang konsep kedaulatan negara, karena konvensi secara prinsip mengharuskan Negara - negara pihak untuk menyelesaikan sengketanya melalui konvensi. (Boer Mauna,2000:377)

Penyelesaian sengketa diatur dalam Bab XV tentang Settlement of Disputes, pas 279 pada intinya menyebutkan bahwa Negara - negara pihak diberi kebebasan yang luas untuk memilih prosedur yang diinginkan sepanajng itu disepakati bersama. Pasal ini mengarahkan penyelesaian sengketa seperti yang dianjurkan dalam pasal 33 (1) Piagam PBB. Pasal 33 (1) Piagam PBB menyebutkan bahwa jika terjadi persengketaan hendaknya diselesaikan dengan cara negotiation, enquity, mediation, conciliation, arbitration, judicial settlement resot to regional agencies or arrangements or other peaceful means on their own choice.

Melihat permasalahan Indonesia dan Malaysia merupakan permasalahan batas wilayah, dimana hal tersebut terkait dengan kepentingan internal masingmasing Negara. Kedua Negara memilih untuk menggunakan beberapa metode untuk menyelesaikannya, diantaranya adalah : 


\section{Instrumen Negosiasi}

Perundingan diplomatis sebagai langkah awal untuk menyelesaikan persengketaan mereka. Hal ini terlihat dari pertemuan pertemuan yang sudah dilakukan oleh perwakilan kedua Negara, bahkan rencananya pada tanggal 23-24 maret 2005 akan diadakan pertemuan tim teknis kedua Negara di Jakarta. Melihat sejarah hubungan Indonesia - Malaysia, cara negosiasi ini merupkan langkah yang tepat dalam menyelesaikan sengketa. Inonesia - Malaysia adalah dua Negara besar di kawasan Aseia Tenggara yang bersahabat inilah yang bias dijadikan dasar untuk mengadakan sebuah perundingan negosiasi dalam rangka mencari solusi yang tepat. Menteri Luar Negeri Malaysia, Syed Hamid Albar, dalam pernyataanya di media cetak nasional Indonesia menyatakan bahwa Indonesia dan Malaysia memiliki hubungan yang sangat dekat dan akrab, tidak ada hal yang tidak bias diselesaikan dengan duduk bersama untuk mendiskusikan sebuah persoalan.

\section{Instrumen Mediasi}

Mediasi adalah negosiasi dengan bantuan pihak ketiga. Dalam mediasi, yang memainkan peran utama adalah pihak-pihak yang bertikai. Pihak ketiga (mediator) berperan sebagai pendamping, pemangkin, dan penasihat. Sebagai salah satu mekanisme menyelesaikan sengketa, mediasi digunakan di banyak masyarakat dan diterapkan kepada berbagai kasus konflik.

Sejarah menyebutkan bahwa Indonesia pernah menempuh cara ini dalam menyelesaikan sengketanya. Mediasi Komisi Tiga Negara (Australia, Belgia dan USA) yangdibentuk PBB bulan agustus 1997 sangat efektif dalam rangka mencari penyelesaian sengketa antara Indonesia dan Belanda, bahkan juga ikut membantu perumusan perjanjia Renville (Boer Mauna,200:192). Mediasi juga banyak digunakan Negara - negara lain sebagai salah satu upaya dalam menyelesaikan persengketaan yang mereka hadapi.

Dalam hal tidak tercapainya suatu pencapaian dengan cara tersebut diatas, konvensi hukum laut 1982 mempunyai metode penyelesaian sengketa yang tidak mengikat (non-yurisdiksional) lainnya, yaitu dengan metode konsiliasi (conciliation) seperti yang diatur dalam pasal 284 dan teknisnya diatur dalam Lmapiran V Konvensi Hukum Laut 1982.

\section{Instrumen Konsiliasi}

Cara penyelesaian perselisihan menurut prosedur konsiliasi ini dimulai dengan pemberitahuan dari salah satu pihak yang berselisih kepada pihak lainnya (pasal 1 Annex V UNCLOS'82). Sekjen PBB akan memegang nama - nama dari konsiliator (juru damai) yang ditunjuk Negara- negara peserta Konvensi dimana setiap Negara dapat menunjuk 4 konsiliator dengan persyaratan bahwa orang orang tersebut mempunyai reputasi tinggi, kompeten dan memiliki intergritas (pasal 2 Annex V UNCLOS'82).

Komisi konsiliasi terdari dari 5 (lima) anggota, 2 dipilih oleh masing masing pihak (sebaiknya dari nama - nama yang ada dalam daftar) dan yang kelima dipilih dari daftar oleh keempat anggota dan akan menjadi ketua komisi (Chairman). Jika penunjukan ini tak dapat terlaksana, maka Sekjen PBB akan menunjukanya dari 
dalam daftar setelah mengadakan konsultasi dengan pihak - pihak yang ebrsangkutan ( pasal 3 Annex V UNCLOS'82).

Keputusan - keputusan tentang masalah proseduril, laporan - laporan dan rekomendarasi dari komisi, dilaksanakan dengan pemungutan suara terbanyak ( pasal 4 Annex V UNCLOS'82).

Komisi akan mendengar pihak - pihak yang berselisih, memeriksa klaim mereka, serta keberatan - keberatan yang diajukan dan menyiapkan usul - usul untuk penyelesaian secara damai (pasal 6 Annex V UNCLOS'82).

Komisi akan memberikan suatu hasil telaahan (report) di dalam waktu 12 bulan sejak komisi terbentuk. Report akan mecatat setiap persetujuan yang dicapai,persetujuan yang gagal, kesimpulan - kesimpulan atas semuafakta dan hukumnya, yang penting bagi masalah yang diperselisihkan dan rekomendasi yang dipandang komisi bermanfaat untuk penyelesain perdamaian. Report akan disimpan dikantor.

Sekjen PBB dan akan segera diteruskan ke masing - masing pihak. Report ini tidak mengikat pihak - pihak menolak report dengan nota tertulis yang dialamatkan ke Sekjen PBB atau apabila jangka waktu 3 bulan telah lewat sejak report disampaikan kepada parah pihak (pasal 8 Annex V UNCLOS'82). Uang jasa dan pengeluaran - pengeluaran komisi dibebankan pada pihak yang berselisih (pasal 9 Annex V UNCLOS'82).

Badan Peradilan yang digunakan untuk menyelesaikan perselisihan perbatasan tersebut adalah Badan Peradilan Internasional. Badan peradilan yaitu badan yang sudah disediakan oleh konvensi sesuai dengan pasal 287 konvensi Hukum Laut 1982, yaitu :

1. Mahkamah / Tribunal Internasional Hukum Laut

2. Mahkamah Internasional Internasional

3. Tribunal Arbitrase

4. Tribunal Arbitrase khusus

Lembaga - lembaga tersebut mempunyai yurisdiksi atas perselisihan yang diajukan tentang interpretasi dan penerapan ketentuan - ketentuan konvensi ini. Khusu untuk Arbitrase khusus, prosedurnya ditentukan dalam Annex VIII serta diperuntukan bagi perselisihan tentang :

1. Perikanan

2. Perlindungan dan pemeliharaan lingkungan kelautan

3. Riset ilmiah kelautan

4. Navigasi termasuk polusi kapal dari dumping.

Adapun lembaga - lembaga yang tersebut diatas adalah lembaga yang mempunyai keputusan mengikat (binding decisions). Setiap keputusan yang dikeluarkan oleh lembaga tersebut merupakan putusan akhir (final decisions).

Indonesia dan Malaysia pernah menggunakan metode penyelesaian sengketa mengikat ini (melalui Mahkamah Internasional) sewaktu menyelesaikan sengketa perebutan Pulau Sipadan dan Pulau Ligitan.

Pada akhirnya dapat dilihat bahwa banyak cara yang bias ditempuh oleh Indonesia - Malayasia dalam rangka menyelesaikan persengketaan mereka, baik secara non - yurisdiksional ataupun yang bersifat yurisdiksional selama itu 
merupakan kesepakatan bersama dan dalam kerangka penyelesaian sengketa secara damai.

Jika terjadi persengketaan antara Indonesia dan Malaysia akan menyebabkan beberapa dampak yang terjadi dalam hubungan kedua Negara, masyarkat ataupun dalam perekonomian diantaranya:

a. Efek jangka pendeknya yang akan terjadi adalah meningkatnya pengangguran di Indonesia secara tajam mengingat tenaga kerja Indonesia (TKI) yang bekerja di Malaysia jumlahnya tidak sedikit. TKI yang bekerja di Malaysia kebanyakan disebabkan faktor sedikitnya lapangan pekerjaan di Indonesia sehingga jika mereka ditarik kembali tentunya berdampak kepada meningkatnya angka pengangguran.

b. Maraknya aksi demonstrasi di kedua Negara yang bersengketa.

c. Memanasnya situasi di daerah - daerah perbatasan kedua Negara yang rawan terjadinya aksi konflik antar masyarakat.

Jika persengketaan menjadi sebuah peperangan antara Indonesia dan

Malaysia maka akan berdampak sebagai berikut :

a. Ekonomi kedua negara akan memburuk, nilai mata uang masing-masing negara tidak stabil, banyak investor yang memilih negara lain yang lebih aman.

b. Pengurangan income di bidang pariwisata, ini sudah pasti, karena para wisatawan mancanegara merasa tidak aman mengunjungi suatu wilayah negara yang berperang, bisa saja Bali akan sepi wisatawan mancanegara.

c. Semua hubungan kedua negara tersebut terputus, padahal kedua negara tersebut saling bergantung dalam hal pariwisata. Warga Malaysia yang mengunjungi Indonesia jumlahnya tak sedikit, merekalah yang menyumbangkan untuk pendapatan negara.

d. Kalau perang, pasti membutuhkan dana untuk kemiliteran, daripada dana itu habis untuk membeli peralatan perang, kemudian alat tersebut hancur saat perang, mending tu biaya untuk pembangunan negri kita ini dan untuk kesejahteraan masyarakat.

\section{Simpulan}

Indonesia, sebagai negara ASEAN yang memiliki wilayah paling luas tidak memiliki ambisi teritorial untuk mencaplok wilayah negara lain. Hal tersebut sangat berbeda dengan Malaysia yang rakus untuk memperluas wilayahnya. Kita semua sudah tahu bahwa titik-titik perbatasan darat Indonesia - Malaysia di Pulau Kalimantan selalu digeser oleh Malaysia. Wilayah kita semakin sempit sementara wilayah Malaysia semakin luas.

Indonesia mempunyai perbatasan darat dengan tiga negara tetangga, yaitu Malaysia, Papua Nugini dan Timor Leste. Sementara perbatasan laut dengan sepuluh negara tetangga, diantaranya Malaysia, Singapura, Vietnam, Filipina, Papua Nugini, Timor Leste, India, Thailand, Australia, dan Palau. Hal ini tentunya sangat erat kaitannya dengan masalah penegakan kedaulatan dan hukum di laut, pengelolaan sumber daya alam serta pengembangan ekonomi kelautan suatu negara.

Sengketa blok Ambalat antara Indonesia-Malaysia tercatat telah sering terjadi. Terhitung sejak Januari hingga April 2009 saja, TNI AL mencatat kapal Malaysia telah sembilan kali masuk ke wilayah Indonesia. Blok Ambalat dengan 
luas 15.235 kilometer persegi, ditengarai mengandung kandungan minyak dan gas yang dapat dimanfaatkan hingga 30 tahun. Bagi masyarakat perbatasan, Ambalat adalah asset berharga karena di sana diketahui memiliki deposit minyak dan gas yang cukup besar. Kelak, jika tiba waktunya minyak dan gas tersebut bisa dieksploitasi, rakyat di sana juga yang mendapatkan dampaknya.

\section{Daftar Pustaka}

Jackson, Robert dan Georg Sorensen, 2009, Pengantar Studi Hubungan Internasional, Yogyakarta: Pustaka Pelajar.

Mas'oed, Mohtar, (1990),Ilmu Hubungan Internasional:Disiplin dan Metodologi, Jakarta: LP3ES

Mas'oed, Mohtar, Colin MacAndrews, 1989, Perbandingan Sistem Politik, Yogyakarta: Gadjah Mada University Press.

Panigoro, Ramdan, Armida S, Alisjahbana dan Parikesit, 2007, Indonesia dan Malaysia Dalam Era Globalisasi Dan Desentralisasi: Isu Dan Permasalahan Politik, Hukum Dan Budaya, Bandung: Univesitas Padjadjaran.

Perwita, Anak Agung Bayu dan Yanyan Mochamad Yani, 2005, Pengantar Ilmu Hubungan Internasional, Bandung: Rosdakarya.

Soeseno, Slamet, 1989, Teknik Penulisan ilmiah Populer, Jakarta: Gramedia

Tarnama, Hilton Putra dan Eka An Aqimuddin, 2011, Mekanisme Penyelesaian Sengketa di ASEAN, Yogyakarta: Graha Ilmu.

Wibowo, M, 2009, Malaysia Membungkam Indonesia,Yogyakarta: Pustaka Solomon.

Wiriatmadja, Suwardi, 1967, Pengantar Ilmu Hubungan Internasional, Surabaya: Pustaka Tinta Mas.

Wuryandari, Ganewati dkk (2008), Politik Luar Negeri Indonesia di Tengah Pusaran Politik Domestik, Yogyakarta: Pustaka Pelajar. 